УДК 005.932:339.1

DOI: $10.15673 /$ fie.v13i2.2039

\author{
Нікішина О.В. \\ доктор економічних наук, старший науковий співробітник \\ завідувач відділу ринкових механізмів та структур \\ E-mail: ksenkych@gmail.com \\ 0000-0002-7172-3551 \\ Тараканов М.Л. \\ кандидат економічних наук, старший науковий співробітник \\ відділ ринкових механізмів та структур \\ Інститут проблем ринку та економіко-екологічних досліджень НАН України \\ Французький бульвар, 29, м. Одеса, Україна, 65044 \\ E-mail: tarakanovnikolajleonidovic@gmail.com \\ ORCID ID: 0000-0002-3827-2373
}

\title{
МАРКЕТИНГОВИЙ ВИМІР МЕХАНІЗМІВ ЛОГІСТИЧНОЇ ВЗАЄМОДІЇ У ЛАНЦЮГАХ ТОВАРНИХ РИНКІВ *
}

У статті обґрунтовано теоретичні положення імплементації маркетингової складової у фрормування механізмів логістичної взаємодії в системі товарних ринків. Уточнено зміст концепції «7R» в напрямі диференціації логістичних сервісів на активні та пасивні, з наступною адаптацією в теорію логістичного маркетингу. Обґрунтовано по відношенню до інструментів контрактації пріоритетні фрорми між ланкових зв'язків, зокрема централізовано-договірні форми в сполученні з використанням інструментів аутсорсингу. В контексті корпоративної логістики визначено області використання механізмів міжланкової взаємодії, що дає можливість розширити вплив маркетингової складової на загальний корпоративний розвиток. Обґрунтовано доцільність використання методу типології в процесі логістичного регулювання процесів злиття та поглинань суб'єктів ринкових ланцюгів. Запропоновано нові області впровадження механізмів логістичної взаємодії, які доповнюють характеристики етапів життєвого циклу товару.

Ключові слова: механізм, маркетинг, логістична взаємодія, концепція «7R», корпоративна логістика, логістична контрактація, логістика життєвого циклу товару.

This work is licensed under a Creative Commons Attribution 4.0 International License http://creativecommons.org/licenses/by/4.0/

Постановка проблеми та її зв'язок 3 важливими науковими та практичними завданнями. В сучасних умовах питання логістичної взаємодії суб'єктів у складі ланцюгів товарних ринків є мало дослідженим й водночас вкрай необхідним. Це пояснюється посиленням уваги науковців і практиків до пошуку додаткових резервів для подолання стагнації в переважній більшості видів економічної діяльності. Вирішення даного актуального питання залежить, зокрема, від врахування впливу маркетингового чинника на формування механізмів міжланкової взаємодії в логістичних ланцюгах товарних ринків (далі ЛЛТР). В умовах пандемічної кризи, суттєвого скорочення споживчого попиту та загострення конкурентної боротьби за ринки збуту одним із головних спільних пріоритетів логістичної взаємодії стає посилення ролі маркетингу в процесі орієнтації товарних потоків на збут продукції.

Сьогодні маркетингова компонента враховується, переважно, в ході досліджень окремих ланок ланцюгів - в закупівельній, виробничій, складській, розподільчій логістиці, тоді як формулювання загальних цілей ЛЛТР не достатньо враховує дану складову. Це призводить до відповідних збитків як на рівні окремих підприємницьких структур, так і ринкових ланцюгів в цілому. Тому розробка теоретикометодологічних підходів до використання механізмів логістичної взаємодії 3 акцентом на маркетингову складову набуває підвищеної актуальності, особливо в умовах загострення кризових явищ в національній економіці. В контексті досліджуваної проблеми додаткової уваги потребують питання впливу логістичної взаємодії на провідні організаційні форми товароруху: міжланкову контрактацію, інтеграційні форми ринкових відносин, етапи життєвого циклу товарів та iн. Даний напрям передбачає розробку адаптивних механізмів з урахуванням маркетингового фактору, що дозволить визначати сучасні тенденції та закономірності у ринкових процесах товароруху.

*Публікацію підготовлено в межах виконання НДР «Формування ефективної логістики товарних ринків» (№ державної реєстрації 0119U000227) 
Аналіз останніх публікацій по проблемі. Різним аспектам логістики товароруху, зокрема, проблемним питанням логістичної взаємодії, логістичного управління та ефективності логістичних ланцюгів товарних ринків, присвячено праці Є.В Крикавського, В.С. Пономаренка, К.М. Танькова, Т.I. Лепейка, О.В. Слетенко, Б.В.Буркинського, В.М. Лисюка, Т.П. Лозової, Н.І. Чухрай, О.М. Сумця, М.Я. Постана, М.Я. Окландера Т.I. Курант, В.Ю. Пономарьової та інших науковців [1-8]. Водночас, використання маркетингової складової у процесі логістичної взаємодії вимагає додаткових досліджень, що буде сприяти підвищенню ефективності товароруху в ринках. Прикладна значимість даного питання посилюється загостренням проблем міжланкових та міжланцюгових диспропорцій, збільшенням частки неповних ЛЛТР, диспаритетним розподілом доходів між учасниками товароруху, підвищенням логістичних витрат та ін. Це обумовлює необхідність розробки відповідного теоретико-методологічного забезпечення механізмів логістичної взаємодії в системі товарних ринків.

Формулювання цілей дослідження. Мета статті - розробка теоретико-методичних основ формування механізмів логістичної взаємодії в ланцюгах товарних ринків із врахуванням маркетингового чинника.

Виклад основних результатів та їх обгрунтування. Під механізмом логістичної взаємодії будемо розуміти сукупність інструментів регулювання міжланкових відносин у процесі переміщення товарів по ланкам логістичних ланцюгів, які характеризуються наявністю зворотних зв'язків між суб' єктами взаємодії, мотиваційним характером відносин, узгодженими інтересами учасників, орієнтацією на забезпечення загальної результативності постачань.

Теоретичні засади формування механізмів логістичної взаємодії з орієнтацією на збут базуються на логістичній концепції (правилі) «7R» [9]. Проведене співставлення функцій логістичних сервісів, які формують правило «7R», сприяло утвердженню думки щодо необхідності їх певного уточнення в ринковому вимірі. Ми пропонуємо таке гіпотетичне твердження: логістичні сервіси мають різну ринкову сутність проявів по відношенню до збуту товарів (рис. 1). Дане твердження має певний набір об'єктивних передумов для його подальшого теоретичного обгрунтування.

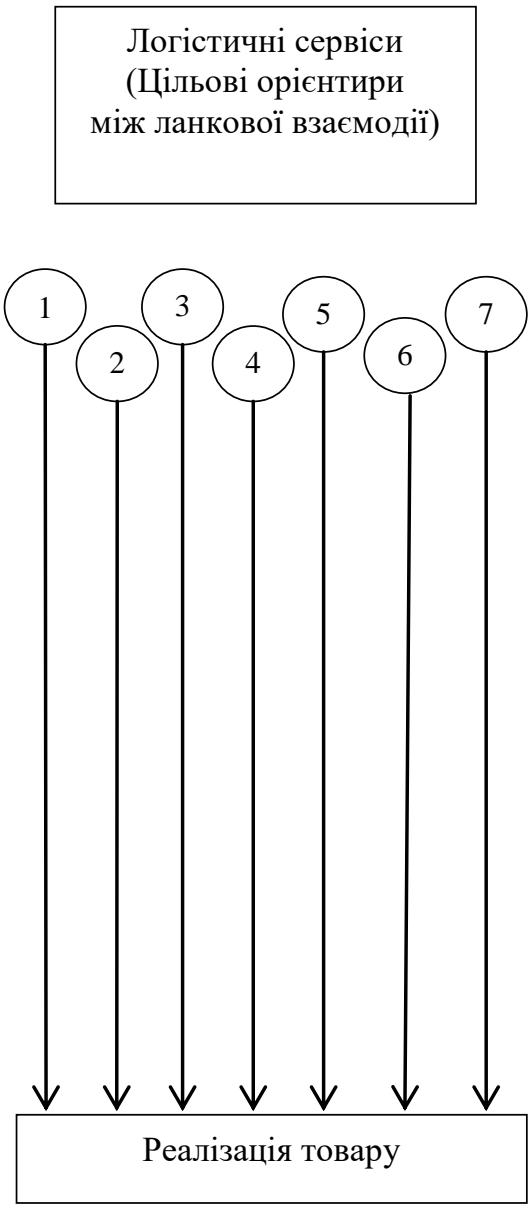

ИСНУЮЧА

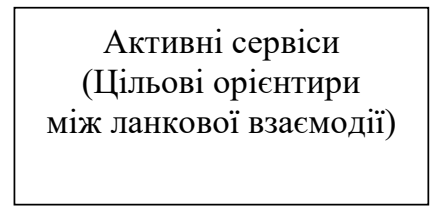

Маркетингові умови Формування цільових Орієнтирів логістичних сервісів

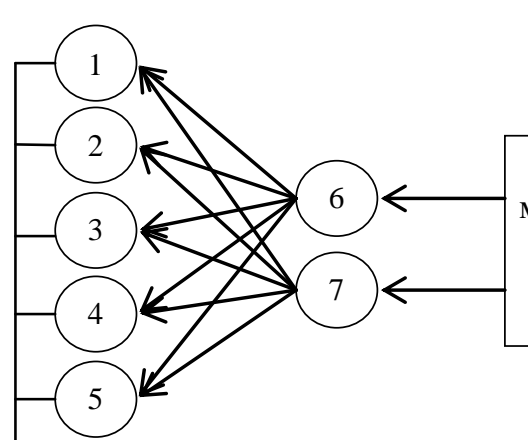

Трансформовані маркетингові передумови пасивні сервіси

Умовні позначення: 1 - необхідний товар; 2 - необхідна кількість товару; 3 - необхідна якість товару; 4 - необхідний термін постачань товару; 5 - необхідний рівень витрат на постачання товару; 6 - необхідне місце постачань товару; 7 - необхідний споживач товару.

Рис. 1. Уточнена логістична концепція «7R» у ринковому вимірі*

*авторська розробка 
По-перше, з точки зору ринкової логістики як інструменту розширеного відтворення товароруху, логістичні сервіси доцільно диференціювати на «активну» та «пасивну» складові. Спільна мета «активних» сервісів полягає у використанні параметрів міжланкової взаємодії, спрямованих на результативне постачання товарів у відповідності до вимог споживчого попиту. До активних сервісів можна віднести такі: необхідний товар (right product), задана кількість товару (right quantity), задана якість товару (right quality), заданий термін постачань товару (right time), необхідний рівень витрат на постачання товару (right cost). Кожний з перелічених сервісів орієнтує логістичний ресурс на ефективне обслуговування одного із параметрів товароруху. Решта сервісів -необхідне місце постачань (right place) та необхідний споживач (right customer) - можна розглядати в якості «пасивних» складових концепції«7R» у зв'язку 3 тим, що вони задають цільові параметри збуту, але не забезпечують їх логістичну реалізацію.

По-друге, диференціація логістичних сервісів на «активні» та «пасиві» актуалізує питання наповнення «пасивних» сервісів новими функціями з метою конструктивної інтеграції в механізми логістичної взаємодії, оскільки вони: (1) не обслуговують параметри товароруху; (2) не мають безпосереднього відношення до забезпечення логістичної результативності постачань; (3) виступають в якості мети, яку мають формуватись параметри «активних» сервісів.

Вищезазначене дозволяє ставити питання про доцільність імплементації «пасивних» сервісів в маркетингову складову товароруху. Так, сервіс «необхідне місце» відповідає умовам прийняття маркетингових рішень у напрямі вибору географічних та товарних меж споживчого попиту. Сервіс «необхідний споживач» доповнює попередній сервіс сегментуванням споживчого попиту в залежності від різних переваг споживачів. У результаті маркетингові рішення на засадах врахування сервісів «небхідне місце» (right place) та «необхідний споживач» (right customer) логічно доповнять решту сервісів і будуть сприяти їх взаємодоповнюючому розгляду.
По-третє, зроблені припущення дають підстави для впровадження концепції «7R» у теорію логістичного маркетингу. Перевірка вищезазначених припущень на практиці дасть можливість уточнити окремі положення даного гіпотетичного твердження та поглибити теоретичне уявлення відносно імплементації сервісів в інтегровану модель логістичного маркетингу.

Розглянемо умови застосування механізмів логістичної взаємодії в складі провідних організаційно-правових форм товароруху в ЛЛТР - контрактації, корпоратизації логістичних процесів, процесів злиття та поглинання, а також в складі етапів життєвого циклу товару.

У механізмах контрактаиіï сучасний тренд у міжланкових відносинах характеризується централізацією договірних відносин. Поширення централізованих форм договірних відносин обумовлено: збитковістю укладання автономних угод між окремими ланками ланцюгів з причин їх нестабільності; підвищеною ймовірністю зміни партнерів в результаті прагнення забезпечити більш вигідні умови договірних відносин за рахунок партнера в ситуації відсутності розвиненої практики взаємовигідних контактів між партнерами по ланцюгу постачань; значною чисельністю та неоднорідністю суб'єктів, які формують товарні потоки (суб'єкти матеріально-технічного забезпечення, переробні підприємства, об’єкти складської логістики, комплекси доробки продукції, транспортні компанії, оптова та роздрібна торгівля), до сукупності яких важко визначати загальні важелі узгодженого функціонування; складнощами 3 використання наскрізних логістичних технологій тощо.

Орієнтація механізмів контрактації на централізоване охоплення максимальної кількості учасників передбачає наявність провідного суб'єкта (виробника готової продукції, крупного оптового чи роздрібного торговця), який спроможний впливати на укладання угод, контролювати їх виконання та забезпечувати рівноправні відносини між учасниками ЛЛТР (рис. 2).

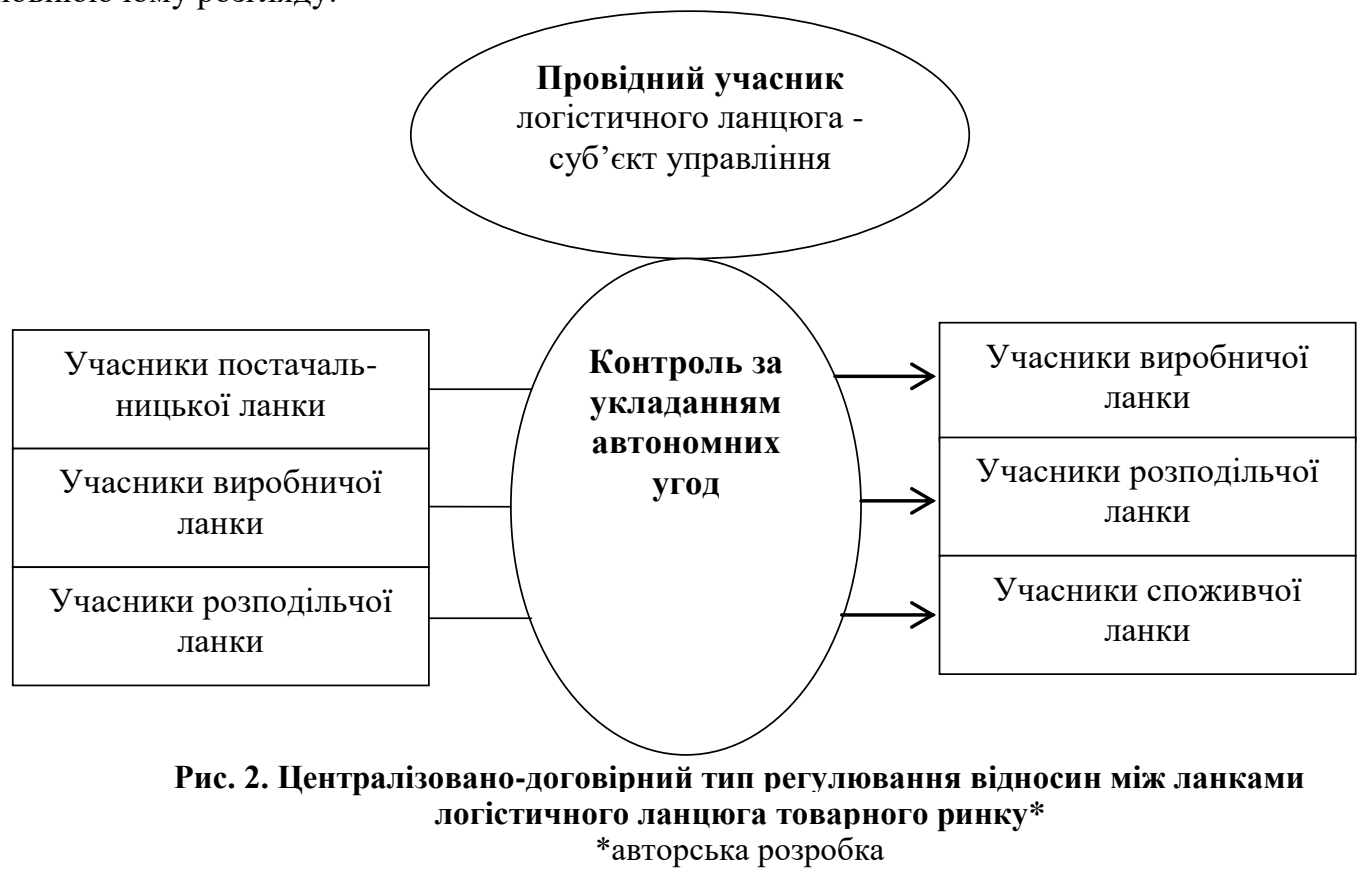


Така форма контрактації передбачає врахування кожним логістичним сервісом специфіки міжланкових відносин в сукупності з забезпеченням довгострокових відносин між складовими ринкового товаpopyxy.

Перспективним різновидом централізованодоговірної форми контрактації виступають договори аутсорсингу. Вони передбачають перерозподіл повноважень між учасниками товароруху на користь компаній, спеціалізованих на виконанні логістичних операцій. Переваги аутсорсингу полягають в отриманні додаткового ефекту за рахунок професійного логістичного обслуговування учасників товароруху $[10,11]$. В результаті утворюються зв'язки між ланками, які функціонують в режимі аутсорсингу, та рештою учасників, що створює різні умови обслуговування суб'єктів на користь аутсорсера. Така ситуація актуалізує задачу забезпечення однакового рівня обслуговування товарних постачань.

В першу чергу, це стосується складових товароруху, які надають комплекс складних операцій. Однією з таких складових виступає функція розподі- лу товаропотоків. Вона включає наскрізне плануванням постачань від товаровиробників до споживачів, доробку товарів, підтримку оптимального рівня товарних запасів тощо. Різноманіття та складність операцій, які мають виконуватись в процесі розподілу товарів, створюють об'єктивні передумови для іiі передачі на аутсорсинг.

Водночас ефективність розподільчого аутсорсингу залежить від попередніх ланок, в першу чергу, від виробничої ланки. Це обумовлено тим, що аутсоpсер в процесі виконання розподільчих операцій спроможний зберегти зафіксовані в результаті виробництва параметри товару, але не спроможний їх поліпшити у випадку низької якості товару. Це призводить до збитків як виробника, так і аутсорсера через скорочення обсягів реалізації товару, зниження його вартості, повернення частини товару тощо. 3 метою мінімізації подібних випадків нами пропонується організаційна схема вибіркової взаємодії аутсорсера i товаровиробника на основі пріоритету маркетингової складової у сервісній концепції логістичного маркетингу (табл. 1).

Таблиця 1

\section{Складові механізму взасмодії аутсорсера (ланка розподілу) і товаровиробника} з забезпечення якості товару*

\begin{tabular}{|l|l|c|}
\hline \multicolumn{1}{|c|}{$\begin{array}{c}\text { Розподільча ланка } \\
\text { (логістичні процедури) }\end{array}$} & $\begin{array}{c}\text { Спільне виконання } \\
\text { процедур товарови- } \\
\text { робником та аутсор- } \\
\text { сером }\end{array}$ & $\begin{array}{c}\text { Виконання проце- } \\
\text { дур аутсорсером }\end{array}$ \\
\hline $\begin{array}{l}\text { 1. Маркетингові дослідження: аналіз ринкової кон’юнктури, } \\
\text { поведінки споживача, варіанти реалізації товару }\end{array}$ & + & - \\
\hline 2. Контроль якості виробництва продукції & + & + \\
\hline $\begin{array}{l}\text { 3. Пошук оптимальних схем розподілу товарних партій проду- } \\
\text { кції між торгівельними мережами. }\end{array}$ & - & + \\
\hline $\begin{array}{l}\text { 4. Забезпечення оптимального рівня запасів по кожному кана- } \\
\text { лу розподілу продукції. }\end{array}$ & - & + \\
\hline 5. Прийом продукції, ії накопичення та складування. & - & + \\
\hline $\begin{array}{l}\text { 6. Вибір маршрутів транспортування продукції до торгівель- } \\
\text { них мереж, оплата експедиторських, страхових послуг по } \\
\text { шляху доставки товару. }\end{array}$ & - \\
\hline
\end{tabular}

*авторська розробка

Так, по відношенню до параметру якості товару організаційна схема передбачає: (1) залучення представників компанії - аутсорсера до контролю за якістю продукції, що виробляється (дотримання умов сервісу «небхідне місце» (right place) в частині узгодження якості товару відносно місць реалізаціі); (2) спільне $з$ аутсорсером сегментування ринків збуту, що посилить відповідальність товаровиробника за якість продукції (дотримання умов сервісу «необхідний споживач» (right customer) в частині узгодження якості товару відносно оптимальних сегментів збуту).

В області інтеграційних відносин пріоритетні напрями запровадження механізмів логістичної взаємодії пов'язані з організаційно-правовими формами корпоратизації, злиття і поглинання, кооперації, державно-приватного партнерства тощо. Особливість інтеграційних процесів полягає в більш глибокому рівні взаємозалежності ланок одна від одної в результаті об'єднання активів, окремих функцій, ринків збуту, інших сфер міжланкових відносин. Позитивні наслідки від інтеграційних зв'язків полягають в укрупненні логістичного бізнесу (ефект масштабу), скороченні трансакційних витрат, в активному залученні інноваційних технологій в логістичний бізнес тощо.

Можна виділити дві головні ознаки корпоративної форми організації логістичної взаємодії у ЛЛТР: (1) наявність значної кількості учасників (підприємств, фірм, організацій переважно однакової секторної спрямованості), які формують завершену структуру корпоративного ланцюга, упорядковану в загальну корпоративну стратегію; (2) функціонування логістичних ланцюгів товарних ринків на засадах завершених циклів від постачань ресурсів до реалізації готового продукту кінцевим споживачам. 
Наявність власної закупівельної логістики, переробних потужностей, розподільчих центрів та збутових мереж створює сприятливі умови для формування загального економічного та правового простору в результаті: (1) впровадження централізованої системи управління логістичними ланцюгами шляхом делегування загальних цільових функцій ланцюгів центральним органам управління корпорацією; (2) скорочення загальних логістичних витрат та оптимізації розподілу доходів між ланками ланцюгів; (3) використання синергійного ефекту в процесі розвитку міжланкових зв'язків.

У межах загального корпоративного простору створюються додаткові передумови для посилення результативності використання маркетингової складової концепція «7R», що пов'язано з можливістю оперативного отримання достовірної інформації про реалізацію продукції не тільки за товарною номенклатурою і споживчими характеристиками, але і особливостями реалізації, а також зі зменшенням роздрібних цін кінцевої продукції за рахунок відсутності торговельної націнки, мінімізацією комерційних ризиків (відсутність міжланкових бар'єрів, взаємодія 3 постійними постачальниками, загальна система управління).

За такого підходу пропонуємо виокремити три корпоративних типи механізмів логістичної взаEмодіï:

1. Тип механізмів, спрямований на усунення неефективних та дублюючих ланок в системі корпоративних ланцюгів товароруху в ринку.

2. Тип механізмів, спрямований на формування корпоративних центрів логістичної взаємодії (розподільчі центри, центри доробки товарів, торгівельні центри). Такі центри доцільно створювати у вигляді дочірніх підприємств, в тому числі на засадах аутсорсингу. Дочірні підприємства мають відповідну свободу прийняття управлінських рішень. Вони призначені посилювати логістичну та маркетингову результативність товароруху в результаті самостійного визначення спеціалізації, масштабів надання послуг, імплементації у загальну корпоративну стратегію. У такій парадигмі центри логістичної взаємодії необхідно орієнтувати на виконання загальнокорпоративних завдань в якості функціонально відокремлених об’єктів управління корпоративною логістикою.

3. Тип механізмів, орієнтований на певні цілі корпоративного розвитку. Такі механізми додатково повинні використовувати інструменти стратегічної логістики, конкурентних переваг, загального інформаційно-корпоративного простору для прийняття оптимальних логістичних рішень.

Перелічені типи механізмів логістичної взаємодії збагачують теоретичні положення ринкової логістики, акцентуючи увагу на можливості розширення та поглиблення впливу корпоративних логістичних ланцюгів на загальний корпоративний розвиток.

В контексті міжланкової взаємодії переваги злиття та поглинань - двох близьких організаційноправових форм проявів інтеграційних процесів - полягають у наступному:

- можливості швидкого нарощування масштабу бізнесу, що забезпечує скорочення витрат на одиницю товару у міру збільшення обсягів продажів;

- централізації маркетингових досліджень, усунення дублюючих функцій, підвищення кваліфікації персоналу, що в цілому призводить до збільшення доходів учасників ЛЛТР;

- об'єднанні найкращих практик та спільних ресурсів для зниження ризиків банкрутства, підвищення інвестиційної привабливості ланцюгів товароруху в ринках;

- можливості лобіювання власних економічних інтересів, зокрема змін у нормативно-правовому забезпеченні логістичних процесів.

Слід зазначити, що процеси злиття та поглинань створюють певні недоліки в сфері логістичного обслуговування цих процесів, зокрема, в результаті втрати налагоджених зв'язків між ланками ланцюгів, що потребує укладанням нових угод для відновлення міжланкових відносин.

Узагальнення різноманітних ситуацій та негативних наслідків від злиття та поглинань надає можливість розглянути питання впровадження механізмів логістичної взаємодії за принципом типових ситуацій. Даний методичний підхід буде сприяти уніфікації інструментів впливу логістики на підвищення результативності процесів злиття та поглинань, скороченню термінів проведення відповідних процедур, всебічному врахуванню як позитивного, так і негативного досвіду врахування логістичної взаємодії в процесах злиття та поглинання. Фрагмент використання механізмів логістичної взаємодії в контексті маркетингової складової розширення ринків збуту наведено в табл. 2.

Таблиця 2

Мотивації використання механізмів логістичної взаємодії за типовими варіантами злиття та поглинань (фрагмент: маркетингова складова розширення ринків збуту)

\begin{tabular}{|c|c|c|}
\hline Типові варіанти & $\begin{array}{c}\text { Мотивації злиття та } \\
\text { поглинань }\end{array}$ & Напрями використання механізмів логістичної взаємодії \\
\hline $\begin{array}{l}\text { 1. Вихід на новий } \\
\text { споживчий ринок }\end{array}$ & $\begin{array}{l}\text { Результативний вихід } \\
\text { та закріплення на } \\
\text { перспективному } \\
\text { споживчому ринку }\end{array}$ & $\begin{array}{l}\text { а) адаптація логістичних ланцюгів до: } \\
\text { - варіантів розміщення об’єктів злиття (поглинань): центра- } \\
\text { льного місцеположення на споживчому ринку (максиміза- } \\
\text { ція додаткових доходів), віддаленого місцеположення на } \\
\text { споживчому ринку (монопольне забезпечення товарного } \\
\text { збуту), фокусного розміщення до окремих споживчих } \\
\text { центрів (охоплення провідних центрів споживання товару); } \\
\text { - процесів централізації товарних потоків; }\end{array}$ \\
\hline
\end{tabular}


Продовження табл. 2

\begin{tabular}{|c|c|c|}
\hline Типові варіанти & $\begin{array}{l}\text { Мотивації злиття та } \\
\text { поглинань }\end{array}$ & Напрями використання механізмів логістичної взаємодії \\
\hline & & $\begin{array}{l}\text { б) адаптація систем ERP ( Enterprise Resource Planning - } \\
\text { планування ресурсів підприємства) до оновленого масш- } \\
\text { табу товарного збуту. }\end{array}$ \\
\hline $\begin{array}{l}\text { 2. Злиття та погли- } \\
\text { нання крупним учас- } \\
\text { ником малого учас- } \\
\text { ника }\end{array}$ & $\begin{array}{l}\text { Підвищення стабіль- } \\
\text { ності на ринку }\end{array}$ & $\begin{array}{l}\text {-забезпечення результативності логістичної взаємодії в } \\
\text { умовах передачі частини функцій крупного учасника бізне- } \\
\text { су малим учасникам на засадах спільних інтересів; } \\
\text { - забезпечення результативності логістичної взаємодії в } \\
\text { процесі укрупнення товарних потоків. }\end{array}$ \\
\hline $\begin{array}{l}\text { 3. Розширення видів } \\
\text { діяльності }\end{array}$ & $\begin{array}{l}\text { Підвищення конку- } \\
\text { ренто } \\
\text { спроможності в рин- } \\
\text { ку за рахунок отри- } \\
\text { мання додаткових } \\
\text { компетенцій }\end{array}$ & $\begin{array}{l}\text {-впровадження дочірніх фірм у логістичні ланцюги товаро- } \\
\text { руху; } \\
\text { - розробка та впровадження механізмів логістичної взаємо- } \\
\text { дії до обслуговування нових видів діяльності }\end{array}$ \\
\hline $\begin{array}{l}\text { 4. Злиття та погли- } \\
\text { нання за кооператив- } \\
\text { ними зв'язками } 3 \\
\text { зовнішніми постача- } \\
\text { льниками }\end{array}$ & $\begin{array}{l}\text { Забезпечення опти- } \\
\text { мального балансу } \\
\text { між власним вироб- } \\
\text { ництвом та поста- } \\
\text { чаннями за коопера- } \\
\text { тивними зв'язками }\end{array}$ & $\begin{array}{l}\text { - врахування фактору предметної та по-детальної спеціалі- } \\
\text { зації в процесі налагодження логістичних зв'язків з дочір- } \\
\text { німи фірмами; } \\
\text { - пристосування механізмів логістичної взаємодії до проце- } \\
\text { сів централізації кооперативних зв'язків у провідних ланках } \\
\text { ланцюгів; } \\
\text { - оптимізація кооперативних зв’язків за критерієм мініміза- } \\
\text { ції логістичних витрат на товарорух. }\end{array}$ \\
\hline
\end{tabular}

Застосування механізмів логістичної взаємодії в процесі життєвого циклу товару включає чотири етапи: виведення товару на ринок, зростання, зрілості та спаду. Для етапу виведення товару на ринок притаманні значна невизначеність освоєння ринку, високі питомі витрати на товарні постачання в умовах обмежених обсягів збуту, вибірковості замовлень тощо. Завдання логістики у цей період полягають у скороченні терміну дії етапу. В теорії життєвого циклу товару по відношенню до даного етапу акцентується увага на необхідності створення товарних запасів, легко доступних споживачам, з метою їх швидкого поповнення при позитивному сприйманні товару споживачами.

В той же час дана умова не враховує іншу суттєву особливість етапу. Вона полягає в тому, що до $70 \%$ часу припадає на логістичне обслуговування пробних постачань [12]. Ця особливість повинна доповнити загальноприйняті ознаки початкового етапу. В таких умовах цільовий орієнтир логістичної взаємодії передбачає посилення ролі маркетингової складової у скороченні терміну пробних постачань шляхом відбору торговельних мереж за критерієм ступеню зацікавленості в диверсифікації товарного асортименту. Складові координаційного механізму представлені на рис. 3. Його зміст полягає у створенні двополюсного режиму логістичної взаємодії, одним полюсом якого виступає виробнича ланка, другим ланка реалізації товару. Суб'єкти цієї ланки (зокрема, торговельні мережі) відбираються за критерієм ступеню зацікавленості в диверсифікації товарного асортименту, що буде сприяти прискореному виведенню товару на споживчий ринок.
Eman зростання характеризується забезпеченням відповідності обсягів постачань задоволенню зростаючого споживчого попиту. На цьому етапі основна увага спрямована на досягнення балансу між якістю логістичних послуг та логістичними витратами на іiі забезпечення. Одночасно важливою складовою етапу є початок протидії конкурентів. Традиційно в теорії життєвого циклу товару вплив протидій конкурентів на збільшення обсягів продажів пов'язують 3 наступним етапом - етапом зрілості [13]. Але розповсюдженню конкурентних відносин на етап зростання відповідає практика конкурентних відносин [14]. Конкуренти розробляють стратегії протидії (підвищують рівень сервісу, пропонують унікальні послуги ін.), їх апробують з метою визначення результативності, незважаючи на переваги, які віддають споживачі новому товару. Запровадження конкурентної протидії дає можливість визначити слабкі сторони заходів, своєчасно їх усунути та скорегувати напрями подальшого конкурентного впливу.

Відтак, включення до ознак етапу зростання характеристики, пов'язаної з початком протидії конкурентів, має об'єктивну основу та буде сприяти реальному відображенню процесів на даному етапі життєвого циклу товару. За таких умов створюються додаткові проблеми щодо реалізації етапу зростання, коли треба одночасно балансувати збільшення обсягів товарних постачань 3 ростом обсягів продажів та одночасно мінімізувати негативні впливи конкурентів на збут товарів. В якості провідного інструментарію етапу зростання доцільно розглянути варіативну логістику. 


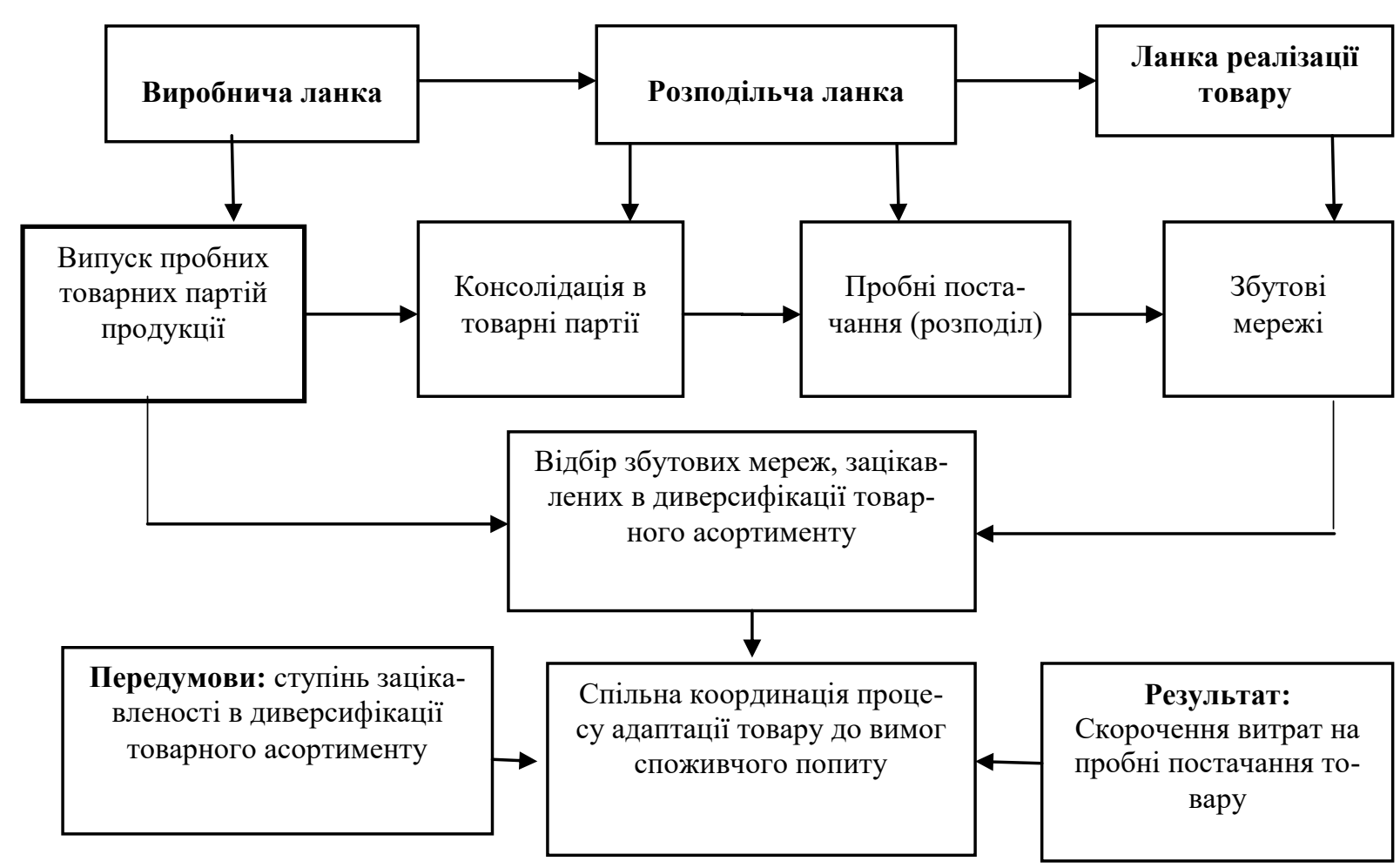

Рис. 3. Складові координаційного механізму пробних товарних постачань* *авторська розробка

В основу варіативної логістики покладено методичний підхід превентивного реагування на зов- нішні впливи. Варіанти превентивного реагування та їх наслідки відображені на рис. 4.

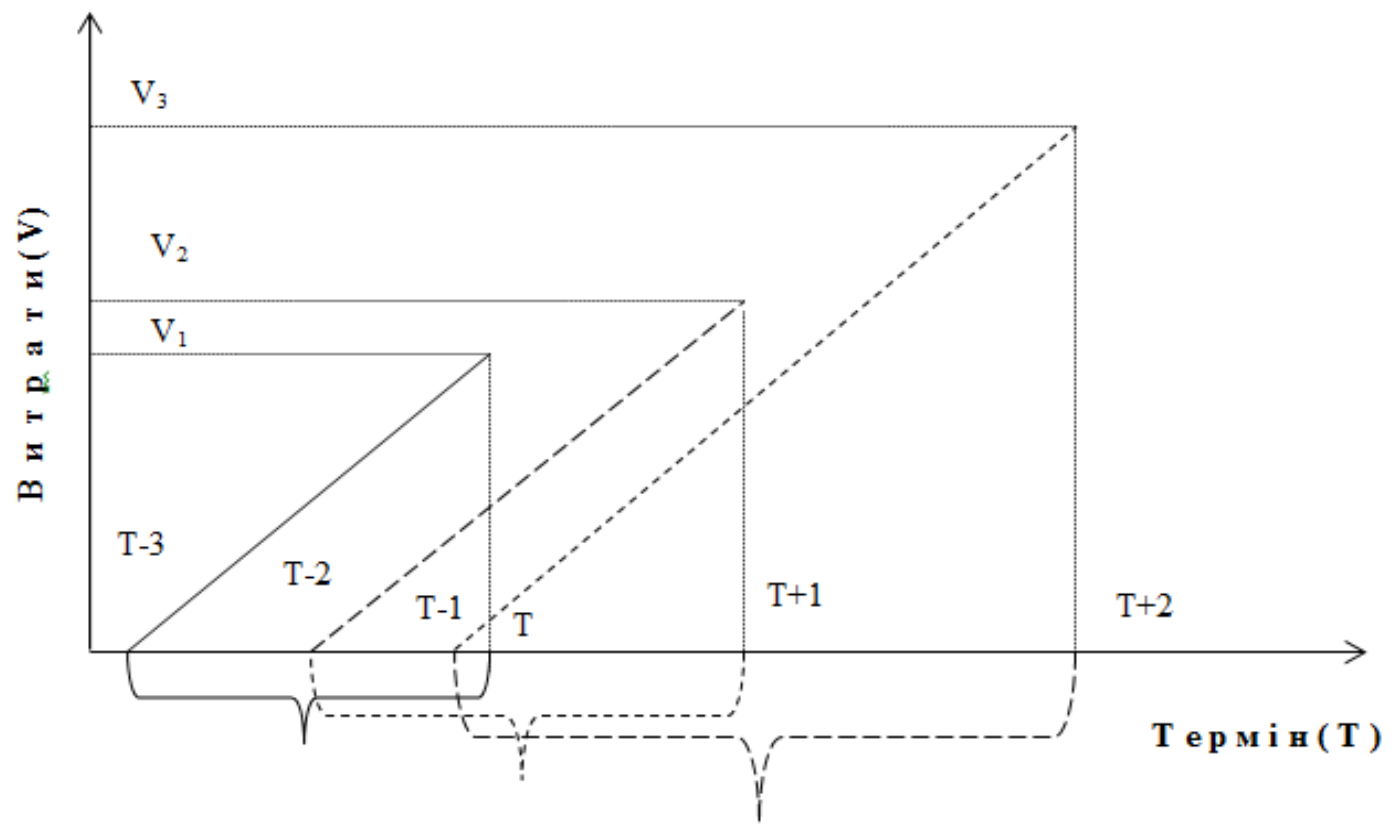

Умовні позначення: Т - час наступу негативного впливу; Т-3, Т-2,T-1 - час початку запровадження превентивних заходів, V1, V2, V3 - обсяги витрат на запровадження превентивних заходів; T+1, T+2 - час завершення превентивних заходів.

Рис.4. Варіанти запровадження превентивного реагування на негативні впливи в процесі зростання товарного ринку та їх наслідки*

*авторська розробка 
Iз наведеного рисунку можна допустити, що за оптимум превентивного реагування доцільно обирати точку перехрестя, в якій термін завершення адаптаційних заходів співпадає з початком проявів негативних впливів (варіант Т-3 = Т, рис.4). 3 даного припущення випливає, що збитки від переорієнтації логістичних ланцюгів на нові умови функціонування зростають у міру збільшення частки незавершених в строк заходів.

Eman зрілості характеризується продовженням конкурентної боротьби за ринки збуту з відповідним іiї посиленням. Загальні цілі логістичної взаємодії постають більш вибірковими в результаті більш поглибленого використання сервісу «необхідний споживач» (right customer), а саме - уточнення сегментації споживчого ринку. Збільшуються витрати на стимулювання збуту, дистрибуцію, сервісне обслуговування товарних постачань. Функція механізмів логістичної взаємодії зосереджується на забезпеченні стабільності відносин товаровиробників 3 оптовими компаніями та роздрібними мережами.

Eman cnady характеризується скороченням обсягів реалізації товару. На даному етапі використовується така форма торгівлі, як розпродаж товару. Логістична взаємодія повинна забезпечити підтримку збуту одночасно з мінімізацією ризиків передвчасної повної відмови від товарів. Механізми виконання даної умови мають зосереджуватись на альтернативних варіантах підтримки маркетингової «поведінки» товароруху, зокрема: (1) поступовому скороченні обсягів товарних постачань у відповідності до скорочення обсягів продажів; (2) повному припиненню товарних постачань разом із реалізацією решти товарів; (3) змінами окремих параметрів товарних постачань (наприклад, пакування товару) з метою зупинки розпродажу з наступним повторним освоєнням споживчого попиту. Таким чином, нами пропонуються нові області впровадження механізмів логістичної взаємодії, які доповнюють теоретичні положення етапів життєвого циклу товару (рис. 5):

1) на етапі виведення товару на ринок - зосередження механізмів логістичної взаємодії на скороченні термінів пробних товарних постачань;

2) на етапі зростання - впровадження механізмів превентивного реагування на дії конкурентів;

3) на етапі зрілості - зосередження механізмів логістичної взаємодії на посиленні протидії конкурентам;

4) на етапі спаду - зосередження механізмів логістичної взаємодії на альтернативних варіантах розпродажу товарного асортименту.

\section{Етапи життсвого циклу товару}

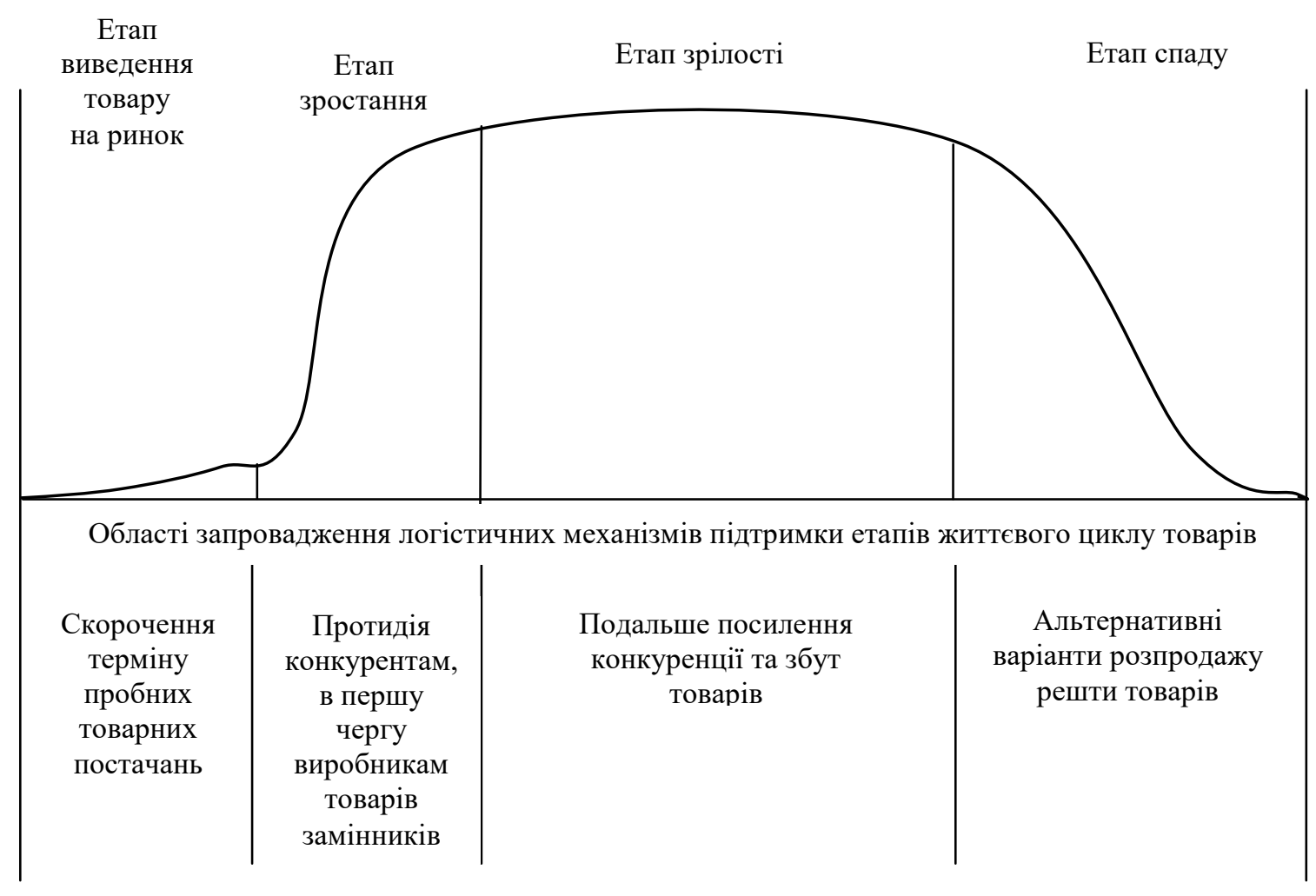

Рис.5. Логістичні інструменти підтримки етпів життєвого циклу товару*

*авторська розробка 
Висновки та перспективи подальших досліджень. В ході дослідження на основі співставлення функцій логістичних сервісів уточнено зміст концепції «7R» в напрямі диференціації логістичних сервісів на активні та пасивні, з наступною адаптацією в теорію логістичного маркетингу. Визначені умови та перспективні області використання механізмів логістичної взаємодії надали можливість сформулювати завдання відносно умов впровадження маркетингового чинника в процеси логістичного обслуговування товароруху.

В сфері логістичної контрактації механізм централізовано-договірних форм логістичної взаємодії доповнено інструментом вибіркової взаємодії аутсорсера і товаровиробника на основі пріоритетного врахування маркетингової складової у сервісній теорії логістичного маркетингу. У дослідженні обгрунтовано додаткові можливості впливу маркетингової компоненти на досягнення загальних цілей корпорацій в результаті делегування загальних цільових функцій ланцюгів центральним органам управління корпорацією, оптимізації розподілу доходів між ланками ланцюгів, оперативного отримання повної інформації про умови реалізації продукції, що забезпечує результативність механізмів логістичної взаємодії в межах корпоративної логістики.

Зроблений висновок щодо запровадження механізмів впливу логістичної взаємодії на процеси злиття та поглинань за методом типових ситуацій сприяє подальшим дослідженням в напрямі визначення наукових підходів до регламентування логісти- чних заходів з одночасною орієнтацією на розширене освоєння споживчих ринків.

Визначені області впровадження механізмів логістичної взаємодії в процеси життєвого циклу товару свідчать про значні резерви врахування маркетингового чинника: (1) на етапі виведення товару на ринок - скорочення терміну пробних постачань шляхом відбору торгівельних мереж за критерієм ступеню зацікавленості в диверсифікації товарного асортименту; (2) на етапі зростання - запровадження методології превентивного реагування на протидії конкурентів; (3) на етапі зрілості - концентрація механізмів логістичної взаємодії на посиленні протидії конкурентам; (4) на етапі спаду - зосередження механізмів на альтернативних варіантах розпродажу товарного асортименту.

Теоретичне значення отриманих результатів дослідження полягає у розвитку теорії ринкової логістики в маркетинговому аспекті механізмів логістичної взаємодії, практичне - в можливості використання науково-прикладних результатів суб'єктами та профільними інституціями ринків в ході розробки організаційно-економічних механізмів формування ефективної логістики на товарних ринках, а також вибору оптимальних форм логістичної взаємодії учасників ринкового ланцюга на засадах логістичного маркетингу.

Використання теоретико-методичних засад логістичної взаємодії в контексті посилення ролі маркетингової складової в ланцюгах товарних ринків створює передумови для подальших розробок у даному напрямі досліджень.

\section{Література}

1. Крикавський Є.В. Логістика. Для економістів. Львів: Видавництво Національного університету «Львівська політехніка», 2004. 448 с.

2. Пономаренко В.С., Таньков К.М., Т.I. Лепейко. Логістичний менеджмент / за ред. В.С. Пономеренко. Х.: ВД «НЖЕК», 2010. 440 c.

3. Єлетенко О.В. Механізм управління логістичною системою підприємства. Вісн. нац. ун-ту «Львів. Політехніка». 2008. № 628. С. 494-498.

4. Методологічні засади формування ефективної логістики товарних ринків: монографія. За ред. Буркинського Б.В., Нікішиної О.В. Одеса: ІПРЕЕД НАНУ, 2020. 200с.

5. Буркинський Б.В., Нікішина О.В. Принципи формування ефективних логістичних ланцюгів товарних ринків: монографія. Одеса : ІПРЕЕД НАНУ, 2019. 85c.

6. Буркинський Б.В., Нікішина О.В. Діагностика ефективності логістичних ланцюгів товарних ринків: наук. доповідь. Одеса: Одеса: ІПРЕЕД НАН України, 2020. 75 с.

7. Логістика товарного ринку: монографія. За ред. Б. В. Буркинського, В. М. Лисюка. Одеса: ІПРЕЕД НАН України, 2018. 244 с.

8. Tarakanov M., Lozova T., Uzun I. Integrated approach to the of logistics and marketing in the system of commodity markets. Economics. Ecology. Socium. Vol. 4, №3. 2020. Pp. 12-23. doi: 10.31520/2616-7107/2020.4.3-2

9. Концепция комплекса маркетинга - модель «7P». URL:

https://studme.org/170673/marketing/kontseptsiya_kompleksa_marketinga_model (дата звернення 3.04.2021)

10. Переваги аутсорсингу. URL: https://tribun.com.ua/44983 (дата звернення 3.04.2021)

11. Логістично-аутсорсингова платформа як основа формування транспортно-логістичної системи регіону. URL: http://www.economy.nayka.com.ua/?op=1\&z=6000http://www.economy.nayka.com.ua/?op=1\&z=6000 (дата звернення 3.04.2021)

12. Розповсюдження зразків товарів. URL: https://i.factor.ua/ukr/journals/nibu/2016/august/issue-62/article20288.html (дата звернення 5.04.2021) 
13. Теория конкуренции. URL:

https://www.sgu.ru/sites/default/files/documents/2017/teoriya_konkurencii_38.03.01_ep.pdf (дата звернення 5.04.2021)

14. Логистика и планирование жизненного цикла товара. URL: https://www.lobanovlogist.ru/library/352/55358/(дата звернення 7.04.2021)

Стаття надійшла 15.04.2021

Стаття прийнята до друку 29.04.2021

Доступно в мережі Internet 21.07.2021

\author{
Nikishyna 0. \\ Doctor of Economics, Senior Researcher \\ Head of Department of Market Mechanisms and Structures \\ E-mail: ksenkych@gmail.com \\ ORCID ID: 0000-0002-7172-3551 \\ Tarakanov M. \\ $\mathrm{PhD}$ in Economics, Senior Researcher \\ of Department of market mechanisms and structures \\ Institute of Market Problems and Economic \& Ecological Research \\ of National Academy of Sciences of Ukraine \\ Frantsuzskiy boulevard, 29, Odesa, Ukraine, 65044 \\ E-mail: tarakanovnikolajleonidovic@gmail.com \\ ORCID ID: 0000-0002-3827-2373
}

\title{
MARKETING DIMENSION OF THE MECHANISMS OF LOGISTIC INTERACTION IN THE CHAINS OF COMMODITY MARKETS
}

The article substantiates the theoretical provisions of the implementation of the marketing component in the formation of mechanisms of logistic interaction in the system of product markets. The content of the "7R» concept has been clarified in the direction of differentiating logistics services into "active» and «passive». The "active» services include such services as the required product (right product), the specified quantity of the product, (right quantity), the specified delivery time of the product (right time), the required level of costs for the delivery of the product (right cost). Each of the listed services orients the logistics resource towards servicing one of the parameters of goods movement in the market. The rest of the services the required place of supply (right place) and the required consumer (right customer) - are referred to as "passive» components of the «7R» concept due to the fact that they set target sales parameters (commodity, geographic), but do not provide their logistic implementation. The conclusion has been made about the expediency of introducing the concept of «7R» as a component in the theory of logistics marketing.

In relation to contracting tools, centralized contractual forms of logistics interaction in combination with the use of logistics outsourcing tools have been identified as a priority. Attention has been focused on ensuring the same level of service for commodity deliveries between the links that operate in the outsourcing mode and the rest of the participants in the commodity circulation. An organizational chart of selective interaction between an outsourcer and a commodity producer has been proposed on the basis of the priority of the marketing component of the service concept of logistics marketing.

New areas of the use of marketing in the processes of logistic interaction in relation to the stages of the product life cycle have been proposed. In relation to the stage of bringing goods to the market, directions of strengthening the role of the marketing component in reducing the time of trial deliveries by selecting retail chains based on the criterion of interest in diversifying the product range have been determined. For the maturity stage, attention has been focused on strengthening measures to counter competitors, in particular, by ensuring the stability of relations between producers and wholesalers and retail chains. At the recession stage, alternative options for logistic interaction were proposed in order to optimize the declining sales while minimizing the risks of premature complete abandonment of the goods.

Key words: mechanism, marketing, logistic interaction, «7R» concept, corporate logistics, logistic contracting, logistics of the product life cycle. 


\section{References}

1. Krykavskyi, Ye. V. (2004). Lohistyka. Dlia ekonomistiv. Vydavnytstvo Natsionalnoho universytetu «Lvivska politekhnika».

2. Ponomarenko, V. S., Tankov K. M., \& Lepeiko, T.I. (2010). Lohistychnyi menedzhment. (V. S. Ponomerenko, Ed.). VD «INZhEK».

3. Yeletenko, O. V. (2008). Mekhanizm upravlinnia lohistychnoiu systemoiu pidpryiemstva. Visn. nats. un-tu «Lviv. Politekhnika», (628), 494-498.

4. Burkynskyi, B. V., \& Nikishyna, O. V. (Eds.). (2020). Metodolohichni zasady formuvannia efektyvnoi lohistyky tovarnykh rynkiv. IPREED NANU.

5. Burkynskyi, B. V., \& Nikishyna, O. V. (2019). Pryntsypy formuvannia efektyvnykh lohistychnykh lantsiuhiv tovarnykh rynkiv. IPREED NANU.

6. Burkynskyi, B. V., \& Nikishyna, O. V. (2020). (rep.). Diahnostyka efektyvnosti lohistychnykh lantsiuhiv tovarnykh rynkiv (p. 75). Odesa: IPREED NAN Ukrainy.

7. Burkynskyi, B. V., \& Lysiuk V.M. (Eds.). (2018). Lohistyka tovarnoho rynku. IPREED NAN Ukrainy.

8. Tarakanov, M., Lozova, T. \& Uzun, I. (2020). Integrated approach to the of logistics and marketing in the system of commodity markets. Economics. Ecology. Socium, 4(3), 12-23. doi: 10.31520/2616-7107/2020.4.3-2
9. Koncepciya
kompleksa
marketinga
model'
«R».

https://studme.org/170673/marketing/kontseptsiya_kompleksa_marketinga_model

10. Perevahy autsorsynhu. https://tribun.com.ua/44983

11. Lohistychno-autsorsynhova platforma yak osnova formuvannia transportno-lohistychnoi systemy rehionu. http://www.economy.nayka.com.ua/?op=1\&z=6000http://www.economy.nayka.com.ua/?op=1\&z=6000 20288.html

12. Rozpovsiudzhennia zrazkiv tovariv. https:/i.factor.ua/ukr/journals/nibu/2016/august/issue-62/article-

13. Teoriya

https://www.sgu.ru/sites/default/files/documents/2017/teoriya_konkurencii_38.03.01_ep.pdf

konkurencii.

14. Logistika i planirovanie zhiznennogo cikla tovara. https://www.lobanov-logist.ru/library/352/55358/

Received 15 April 2021

Approved 29 April 2021

Available in Internet 21.07.2021

Цитування згідно ДСТУ 8302:2015

Нікішина О. В., Тараканов М.Л. Маркетинговий вимір механізмів логістичної взаємодії у ланцюгах товарних ринків // Економіка харчової промисловості. 2021. Т. 13, вип. 2. С. 39-49. doi: 10.15673/fie.v13i2.2039

Cite as APA style citation

Nikishyna, O., \& Tarakanov, M. (2021). Marketing dimension of the mechanisms of logistic interaction in the chains of commodity markets. Food Industry Economics, 13(2), 39-49. doi: 10.15673/fie.v13i2.2039 